scholarly character can only be properly appreciated by those of wider experience and fuller knowledge of the progressive emancipation of this medical science from its pragmatic origins.

The formative period of Oertel's life was at the time when many young graduates in the United States had come to realize the impact on medicine of the remarkable developments that had taken place during the later nineteenth century in Germany as a result of the mutual fertilization of the medical and fundamental biological siences. Although to him a problem in. pathology always appealed as a scientific inquiry that took origin from a wish for a better understanding of causal phenomena in disease, he showed none of that lack of appreciation, not unknown among medical scientists, of the humanitarian demands of medicine. But, like some of the more far-sceing of his contemporaries in his country of adoption, he came early to realize that natural philosophy does not necessarily lose its interest by possessing useful applications, and that efforts to solve the problems presented by disease are not necessarily without intellectual attraction. It was the effort to combine the searchings of the philosopher with the responsibility of the physician that distinguished Oertel's contributions to pathology.

G. Payling Wright

\section{Mr. Sidney G. Starling}

Sidney G. Starling died on December 16, at the age of eighty-two. He was born in Bradford and received his early education at the Grammar School and Technical College. Having obtained an exhibition and national scholarship, he entered the Royal College of Science, London, in 1891 under Prof. Rücker. Here he secured first-class honours, prizes and medals and worked as assistant and demonstrator during 1893-95. Working under C. V. Boys, he undertook the calculations required for the determination of the Newtonian constant of gravita. tion. Between 1895 and 1898 he was assistant lecturer in mathematics and physics at Battersea Polytechnic, during which time he graduated at the University of London and was awarded the Neil Arnott Exhibition and Medal. At the opening of the West Ham 'lechnical Institute in 1898, he was appointed the first head of the Department of Physies and Mathematics, a post he held until his retirement in 1932. In 1899 he married Miss M. Briggs, who was an assistant in the Art Department at Battersea.

Throughout his lifetime, he was an active member of the Board of Studies in Physics in the University of London and a member of the Faculty of Science. In his earlier years he was an extensive abstractor of Continental papers for the Institution of Electrical Engineers and the Physical Society of London. In 1920 he was elected Fellow of the Institute of Physies.

Starling is probably most widely known as a writer of text-books of physics. The association of Duncar (the engineer) with Starling (the physicist) in the production of their "Text Book of Physics" (1918) was suggested by Sir Richard Gregory, of whom Starling was a great friend. Starling's own "Electricity and Magnetism for Advanced Students" (1912) has been a standard text-book throughout the yoars, appearing in many editions, the latest being rovised in collaboration with A. J. Woodall in 1953. During his retirement there have appeared "Mechanical Properties of Matter" (1935), "Physics" (in col- laboration with A. J. Woodall, 1950) and a revision of "Science in the Service of Man-Electricity" (in association with his son-in-law, H. J. Gray, 1949).

Staff and students respected Starling for his sympathetic understanding, scientific integrity and the quiet efficient way he solved technical and organization problems. There was not the slightest procrastination or duplication of effort. $\mathrm{He}_{\Theta}$ was a strict disciplinarian and a stickler for punctuality. The ease with which he could erect apparatus for research or demonstration was particularly noteworthy. His published researches and writings do not convey his skill and versatility in this direction. In particular, he did pioneer work on aeroplane compasses (theoretical and experimental) at the time of the First World War.

All his hobbies were characterized by high achievement with apparently little exertion, ranging from shooting, golf and photography to silver smithing. From 1912 he had taken a very active part in Freemasonry. Only his closest friends will have appreciated his keen sense of humour, and even they can scarcely realize the many kindly acts of sympathy and encouragement he rendered to those in adversity. $\mathrm{He}$ is survived by a son and daughter.

WILIIAM SWAINE

\section{Dr. George Slater}

Dr. George Stater, one of the leading glaciologists of Great Britain, died at the age of eighty-one on January 27. He started his geological career when a schoolboy at St. John's College, York. Later, he continued as an amateur geologist while a school. master at Haltwhistle, Northumberland (1895-97), and at Ipswich (1897-1918). He showed an early interest in palæontology, but at Ipswich, to quote Dr. F. A. Bather, he "became entangled with the complicated drifts of Suffolk". Patiently he mapped and recorded the structures seen in these disturbed drifts, in temporary sections, on successive faces in sand-pits and, during the First World War, in trenches dug for Army training. Though he published little during this early period, he became recognized as an authority on the glacial drifts of East Anglia, and in 1907 and 1911 led field excursions of the Geologists' Association at lpswich.

He entered the Imperial College (Royal College of Science) in 1918 and remained a member of the geological staff until his retirement in 1939, having obtained the degree of D.Sc. (London) in 1926. The Geological Society awarded him the Murchison Fund in 1928, and in 1950 he received the Foulerton Award 'of the Geologists' Association.

Slater's research work was predominantly concerned with glaciology; and in 1921, when he accompanied the Oxford University Expedition to Spitsbergen as glaciologist, he was able to compare the structures seen in living glaciers with those that he had observed in the drift deposits of East Anglia. The results of his Spitsbergen work were published in the Journal of Geology $(33,4.08 ; 1925)$, and the next year he enunciated his ideas on "Glacial Tectonics as reflected in Disturbed Drift Deposits" (Proc. Geol. Assoc., 37, 392; 1926). Between 1925 and 1932, at least fourteen papers dealing with various aspects of this theory were published. In them he described, often in meticulous detail, the structures seen in disturbed drifts and in glaciers. His theory that these drift structures were actually 